\title{
Finance
}

UDC 657.372.3:664+338.439

doi: 10.12958/1817-3772-2019-4(58)-100-105

D. Lazarenko,

DrHab (Economics), Associate Professor, lazd77@gmail.com,

Slavyansk Educational and Scientific Institute of State Fiscal Service of Ukraine, Slavyansk,

S. Sirenko, Senior Lecturer of the department of accounting and auditing Donbas State Pedagogical University, Slavyansk,

H. Dzwigol, PhD, DrHab (Economics), Professor, ORCID 0000-0002-2005-0078, henryk.dzwigol@poczta.fm,

M. Dzwigol-Barosz, PhD, DrHab (Economics), Professor, ORCID 0000-0002-5306-3836, mariola.dzwigol-barosz@polsl.pl,

Silesian University of Technology, Poland

\section{BASIC ACCOUNTING ASPECTS OF AMORTIZATION POLITIK AND IT'S ROLE IN THE PROCESS OF PROCEEDING IN THE FIXED ASSETS (PROPERTY, PLANT AND EQUIPMENT) OF FOOD ENTERPRISES}

Introduction. Studying the development of trends of the food industry allows us to reveal the current conditions for organizing its investment and innovation activities, the main of which include: incomplete use of existing capacities due to insufficient investment; restrictions on updating the material and technical base of industry enterprises and increasing the competitiveness of their products and services; poor development of investment and innovation infrastructures; imperfection of depreciation and monetary policy. This approach allows us to justify the need to strengthen structural integrity and increase the effectiveness of the relationship between participants in investment and innovation activities of food enterprises.

\section{Methods}

Results. The article identifies and discloses the economic nature of accounting depreciation, its impact on income tax expense through the deferred tax mechanism. The factors on which the depreciation amount depends are highlighted. A comparative analysis of the main methods of depreciation are performed.

Prospects. According to the activity or use of the asset, depreciation methods appropriate to that activity are selected. For smooth depreciation, uniform or constant accrual methods are selected. To increase depreciation over time, accruing accruals are used. To reduce depreciation - methods are reduced accruals.

Formulation of the problem. The most serious problem of accounting for depreciation is that there is no generally accepted distribution method. None of the depreciation methods used are better than others in every way. Before applying certain methods of distribution of initial or replacement cost, it is necessary to calculate:

- The value of the asset at the time of acquisition or its replacement cost at a later date;

- Expected service term of assets;

- Residual value at the time of the sale of this asset.

Accurately determining the future value of these quantities is quite problematic. Although they can be calculated on the basis of multiple probabilities, obtaining estimates at the level of an individual asset remains a complex problem.

Research Analysis. A large number of works by foreign and domestic scientists have been devoted to the problems of essence, accounting, and the economic justification of depreciation and such scientists as E. Hendricksen, M. Van Breda, B. Needles, H. Anderson, D. Caldwell, V. Paly, A. Soloviev, N. Vakhrushina, L. Melnikova, N. Plaskova, D. Lazarenko, S. Golov, V. Kostyuchenko and others made a significant contribution to theory and practice.

Formulation of the problem. The aims of this article are:

- Consideration of traditional accounting depreciation as a rational and systematic method of distribution of cost (expenses) for reporting periods.

- To show how the problem of sufficiency of financial resources can be solved, to some extent, using the mechanism of deferred taxes. 
- The role of depreciation policy in the application of the investment and innovation program of the enterprise is considered.

Research results. The task that the management of food enterprises faces in the process of organizing its investment and innovation activity is, first of all, to ensure a balance between the goals and the specific investment and innovation program of the enterprise, and ensure their achievement. Investment processes and activities, projects and programs developed by food enterprises should take into account current trends and conditions for organizing its investment and innovation activities, as well as be consistent with the needs of the food industry, the agricultural sector and alternatives for the prospective development of the industry enterprise itself [7-15].

The process of determining the directions of prospective development of the industry establish general directions, the promotion of which ensures the growth and strengthening of the position of food enterprises. From these positions, the investment and innovation activity of food enterprises should be understood as a set of target settings for the detailed development of specific investment and innovation plans, implemented in accordance with applicable law and aimed at a significant update of the basic production assets of the industry enterprises. At the same time, to organize investment and innovation activities and determine alternatives for the prospective development of food enterprises, it is necessary to provide:

- achievement of the maximum possible economic and social effects from the considered events

- for each investment process and event (project), are used methods for evaluating effectiveness, and then choose those that, all other things being equal, provide the subject of investment and innovation with maximum efficiency;

- the achievement of such level of results of the implementation of investment and innovation processes and measures that would allow creating conditions for the further development of food enterprises;

- rational disposal of fixed assets is aimed at their effective depreciation and timely updating;

- minimization of investment risks associated with the implementation of investment processes and activities (projects);

- the conformity of measures carried out in the framework of the investment and innovation activities of food enterprises with legislative and other legal acts of Ukraine.

In order to improve the investment support of food enterprises based on existing alternatives for perspective development, it is necessary to reform the investment and depreciation systems, to develop the principles of self-regulation of the depreciation policies of enterprises.

Well-known main stages of the life cycle of an enterprise activity: establishment; intensive growth; stabilization (maturity); decline (aging).
The authors consider that in the first two stages, when the problem of sufficiency of financial resources is most urgent, it is exactly some "accounting tricks" associated with depreciation policy can to some extent solve it.

Depreciation is an accounting method that allows in a systematic and rational way to distribute expenses or the cost of capital assets (minus liquidation cost) throughout their entire life time [5].

In particular, the Art. 138.3.1. of Tax Code of Ukraine allows an enterprise to use the same methods of depreciation as for financial accounting purposes. Using various methods of depreciation for tax and financial accounting, an enterprise can find such a combination that will lead to the occurrence of deferred tax liabilities (DTL), that is, to reduction of tax payments (preservation of financial resources) for a certain period of time. Deferred tax liability - the amount of income tax that will be paid in the following periods from temporary tax differences liable to taxation (Regulations (Standards) of Accounting 17).

In the opinion of the authors from the position of accounting estimates of fixed assets are of particular interest problems connected with:

- revaluation of fixed assets in accounting without revaluation in tax accounting;

- applying various methods of wear in accounting and tax accounting.

In both cases, the concepts of deferred taxes appear in accounting (Regulations (Standards) of Accounting 17 , and in the tax accounting in the second case of difference (Art. 138 of Tax Code of Ukraine). Now we will consider the problems of revaluation on the example. Let's assume that some enterprise in accounting and tax accounting uses the straight-line method of depreciation assessment (Regulations (Standards) of Accounting 7, Art. 138 of Tax Code of Ukraine).

On the balance sheet of this enterprise as of December 31, 2016:

- original cost - $8000000 \mathrm{UAH}$;

- amount of contribution - $4800000 \mathrm{UAH}$;

- residual (book) value - $3200000 \mathrm{UAH}$;

- useful life -20 years;

- depreciation rate $-1 / 20(0,05)$.

As of December 31, 2016, the company decided to reassess the cost of the construction. Current (market) cost of the construction according to the expert opinion is $4000000 \mathrm{UAH}$.

Revaluation index according to regulations (Standards) of Accounting $7-4000000 / 3200000=1,25$. After the revaluation, the accounting and tax data will look like this.

\section{Financial Accounting:}

- original cost $-8000000 * 1,25=10000000 \mathrm{UAH}$;

- amount of contribution $-4800000 * 1,25=$ $6000000 \mathrm{UAH}$;

- residual (book) value $-10000000-6000000=$ $4000000 \mathrm{UAH}$; 
- amount of revaluation $-4000000-3200000=$ 800000.

\section{Tax accounting:}

- original cost - $8000000 \mathrm{UAH}$;

- amount of contribution - $4800000 \mathrm{UAH}$;
- residual (book) value $-8000000-4800000=$ $3200000 \mathrm{UAH}$

Let's consider the movement of relevant values in accounting and tax accounting in the following (from the date of revaluation) two years (Table 1).

\begin{tabular}{|c|c|c|c|c|}
\hline \multirow[t]{2}{*}{ No. } & & \multicolumn{3}{|c|}{ Amount, UAH } \\
\hline & & 31.12 .2016 & 31.12 .2017 & 31.12 .2018 \\
\hline 1 & \multicolumn{4}{|c|}{ Tax accounting data } \\
\hline 1.1 & $\begin{array}{l}\text { Book value (the tax base) at the beginning of } \\
\text { the period }\end{array}$ & 8000000 & 32000000 & 2800000 \\
\hline 1.2 & Amortization charge for the year & 4800000 & 400000 & 400000 \\
\hline 1.3 & Book value(the tax base)at the end of the period & 3200000 & 2800000 & 2400000 \\
\hline 2 & \multicolumn{4}{|c|}{ Financial accounting data } \\
\hline 2.1 & Initial cost & 10000000 & 10000000 & 10000000 \\
\hline 2.2 & Amount of accrued depreciation & 6000000 & 6500000 & 7000000 \\
\hline 2.3 & Book value at the end of the period & 4000000 & 3500000 & 3000000 \\
\hline 3 & Temporary difference (p. $2.3-$ p.1.3) & 800000 & 700000 & 600000 \\
\hline 4 & Deferred tax at the beginning of the year & 0 & 144000 & 126000 \\
\hline 5 & $\begin{array}{l}\text { Deferred tax for the year } \\
(\text { p. } 3 * \text { tax rate } 18 \%)\end{array}$ & 144000 & $\begin{array}{c}(700000-800000) * 18 \%= \\
(18000)\end{array}$ & $\begin{array}{c}(600000-700000) * 18 \%= \\
(18000)\end{array}$ \\
\hline 6 & $\begin{array}{l}\text { Deferred tax at the end of the year } \\
\text { (p. } 4+\text { p.5) }\end{array}$ & 144000 & $\begin{array}{c}144000-18000= \\
126000\end{array}$ & $\begin{array}{c}126000-18000= \\
108000\end{array}$ \\
\hline
\end{tabular}

In financial accounting, procedures that reflect deferred taxes (in the case of example - deferred tax liabilities) in determining the income tax expense associated with the revaluation have the following form:

December 31, 2016 Debit Profit tax expense - for the amount determined in the Report about financial results

Credit Current profit tax - for the amount determined in the profit tax declaration Credit Deferred tax liability - $144000 \mathrm{UAH}$

December 31, 2017 Debit Deferred tax liability $18000 \mathrm{UAH}$

Credit Current profit tax - $18000 \mathrm{UAH}$

December 31, 2018 Debit Deferred tax liability 18000 UAH

Credit Current profit tax -18000 UAH.

In all subsequent reporting periods (at the end of the period), similar entries should be made until the deferred tax liability is 0 .

Thus, in order to increase the efficiency of the structure of investment resources for the implementation of food enterprises of investment and innovation activity, it is necessary to implement a set of activities aimed at improving tax accounting, investment policy, minimizing the costs of improving the structure of investment resources according to specific criteria. Formed in the Ukrainian economy, including food enterprises, the structure of investment resources is deformed and inefficient. It is characterized by the superiority of its own sources of financing of investments by food enterprises. Depreciation policy, unlike in countries with developed market economies, plays a very minor role in the process of capital investment and timely renewal of fixed assets of Ukrainian food enterprises [2].
In this sense, it is important for a competent accounting and auditing specialist to master new methods of working with business information. In modern economic science, there are not enough qualitative (technical and economic) criteria for the formation of accounting and depreciation policy. Among the quantitative indicators, only money meter is used that characterizes the original (or residual) cost and a periodic indicator characterizing the useful life of the objects. Liquidation cost in many cases is not used or is equal to zero.

Fixed assets, as provided for in the relevant accounting provision, are the material assets that the enterprise contains for the purpose of using them in the process of production or supply of goods, providing services, renting to other persons or for the performance of administrative and socio-cultural functions, the expected useful life (operation) of which is more than one year (or an operational cycle if it is more than a year) [1].

Over the entire period of operation, fixed assets lose their usefulness, which is characterized by a decrease in their economic benefits in the amount of the excess of the residual value of the asset over the amount of the expected compensation.

Therefore, the use of non-current assets in economic activities provides for the determination of the intensity of their operation with a view to their future renewal. But this indicator (intensity of operation), although it characterizes the degree of wear, does not determine the amount of depreciation charges. In addition, not for all economic entities it is possible to determine the exploitationing intensity at all. We consider that the effective use of fixed assets and ensuring their timely renovation should take into account the physical and technical qualities of the object and its exploitative characteristics. This approach will give to an accountant 
clear criteria for allocating the initial cost of fixed assets between financial periods and will be the basis for the formation of a depreciation policy depending on the use conditions of use of the facilities.

First of all, a clear definition of the economic nature of the object is important for choosing the method of distributing the value of an object (depreciation method) of fixed assets. The economic grouping of objects by their types almost corresponds to the grouping in terms of accounts.

As it can be seen from the table it is possible only for machines, equipment and vehicles to determine a measure of the intensity of operation of objects.

The ability to determine the intensity of operation of fixed assets by their types

\begin{tabular}{|l|c|l|l|}
\hline \multicolumn{1}{|c|}{ Objects } & Score & \multicolumn{1}{|c|}{ Characteristic } & \multicolumn{1}{|c|}{$\begin{array}{c}\text { Determination of the in- } \\
\text { tensity of exploitation }\end{array}$} \\
\hline Land plots & 101 & $\begin{array}{l}\text { Land plots, including those obtained by state (treas- } \\
\text { ury) and municipal enterprises on a permanent basis }\end{array}$ & $\begin{array}{l}\text { Not depreciated } \\
\text { Land reclamation capital ex- } \\
\text { penditures }\end{array}$ \\
\hline $\begin{array}{l}\text { Buildings, structures and } \\
\text { transmission devices }\end{array}$ & 102 & $\begin{array}{l}\text { Capital investments in land improvement (reclama- } \\
\text { tion, drainage, irrigation and other works) }\end{array}$ & Not depreciated \\
\hline Machinery and equipment & 104 & $\begin{array}{l}\text { Houses, structures, their structural components and } \\
\text { transmission devices, as well as residential buildings }\end{array}$ & Impossible \\
\hline Vehicles & 105 & Machinery and equipment for various purposes & Possible \\
\hline $\begin{array}{l}\text { Tools, devices, equipment } \\
\text { (furniture) }\end{array}$ & 106 & Tools, devices, equipment (furniture) & Possible \\
\hline Animals & 107 & Animals & Impossible \\
\hline Perennial plantings & 108 & $\begin{array}{l}\text { Long-term biological assets, including perennial } \\
\text { plantings that are not related to agricultural activities }\end{array}$ & Impossible \\
\hline Other main facilities & 109 & Fixed assets not included in other articles & In most cases possible \\
\hline
\end{tabular}

The next stage should take into account the location of the object's operation and their impact on production or other operating (commercial, agricultural) activity.

According to the national financial legislation, the depreciation method is chosen by the enterprise independently, taking into account the expected method of obtaining economic benefits from its use and the economic role in the economic environment.

Thus, the type of object, its role and method of use determine the dependence of the depreciation amount on two criteria:

1. Useful time.

2. Intensity of operation.

Financial accounting defines 4 depreciation methods that constitute the amount of wear depending on the useful life (straight-line, reduction of residual value, accelerated reduction of residual value, cumulative). All these methods (temporary) do not take into account the degree of physical wear of objects as a result of their operation in the process of economic activity.

With such a variety of temporary depreciation methods, it seems very strange to have only one (industrial) method that puts the economic wear of the objects directly dependent on the degree of exploitation. From the point of view of cost effectiveness, it is the dependence of the amount of accrued wear on the intensity of exploitation of the objects that seems to be a more rational way of allocating the value of the fixed assets. Then, the amount of economic (accounting) wear will be as close as possible to the actual physical wear of the object. We consider it necessary to investigate the theory of industrial method in more detail, and to enrich the practice of its application.
A form of industrial method of depreciation is the method of calculating depreciation on the basis of margin income.

The essence of this approach is to assess the contribution to the marginal income of a non-current asset(s). The total value of a non-current asset(s) is allocated to the reporting periods in proportion to that contribution.

The calculation of the amount of depreciation is carried out with the help of the ratio of the value of noncurrent asset(s) to the expected amount of marginal income in a specific reporting period (1):

$$
K=\frac{F}{\sum_{t=1}^{n} C_{t}},
$$

where $K$ - coefficient of the cost of non-current asset (s) to the amount of expected total marginal income;

$F$ - amortized cost of a non-current asset(s);

$C^{t}$ - the expected amount of marginal income for the reporting period $t$ during the life of the fixed asset (s).

The amount of annual depreciation $\left(A^{t}\right)$ is determined by the following formula 2 :

$$
A^{t}=K \times C^{t} .
$$

According to the authors, this approach most fully complies with the basic accounting principle - the calculation and accordance of income and expenses.

In accounting, depreciation is the process of allocating the cost of purchased non-current assets for the reporting periods from the use of these non-current assets. 
Allocation is the process of dividing a sum into components by relating the latter to the objects of accounting or reporting periods [5].

The most serious problem of accounting of depreciation is that there is no generally accepted distribution method. None of the methods is better than any other.

When using each of the depreciation methods, it is necessary to determine:

- the cost of a non-current asset at the time of its purchase or its

- retrievable amount at a later date;

- life expectancy of non-current asset;

- liquidation cost at the time of dropping out of the non-current asset.

These values represent unspecified future costs. Although they can be calculated on a probabilistic basis, obtaining assessments at the level of an individual asset is a complex problem due to the complex interaction of non-current assets in the process of making profit, as well as the uncertainty of the relationship between expenses and incomes at the level of a separate non-current asset.

In the case of the industrial method, there is a problem of choosing a measure that determines the degree of intensity of exploitation corrects the degree of wear. For example, for a truck, a measure of exploitation is a quantitative indicator that characterizes the distance traveled (mileage). But using such a criterion as a depreciation rate does not take into account the degree of workload and the empty path. And for specialized transport, mileage is generally of minor importance after the number of work performed (manipulations).

Table 3

Use of criteria for determining the intensity of operation

\begin{tabular}{|c|c|c|c|}
\hline Objects & Functional role & The indicator of the degree of intensity of use & Measurer \\
\hline \multirow[t]{3}{*}{ Vehicles } & Cargotransportation & $\begin{array}{l}\text { Number of traveled distance } \\
\text { Degree of workload }\end{array}$ & $\begin{array}{l}\text { Absolute }(\mathrm{km}) \\
\text { Relative }(\%)\end{array}$ \\
\hline & Passenger transportation & $\begin{array}{l}\text { Number of traveled distance } \\
\text { Number of passengers carried }\end{array}$ & $\begin{array}{l}\text { Absolute (km) } \\
\text { Absolute (units) }\end{array}$ \\
\hline & Specialized functions & $\begin{array}{l}\text { Number of work performed } \\
\text { Number of manipulations } \\
\text { Number of traveled distance }\end{array}$ & $\begin{array}{l}\text { Absolute (pcs.) } \\
\text { Absolute (units) } \\
\text { Absolute (km) }\end{array}$ \\
\hline \multirow[t]{3}{*}{ Equipment } & Production & $\begin{array}{l}\text { The number of manufactured products } \\
\text { Working hours } \\
\text { Degree of workload }\end{array}$ & $\begin{array}{l}\text { Absolute (units) } \\
\text { Absolute (h) } \\
\text { Relative (\%) }\end{array}$ \\
\hline & $\begin{array}{l}\text { Implementation of pro- } \\
\text { ducts (cooling) }\end{array}$ & $\begin{array}{l}\text { Working hours } \\
\text { Amount of energy consumed }\end{array}$ & $\begin{array}{l}\text { Absolute (h) } \\
\text { Absolute (kW) }\end{array}$ \\
\hline & Power supply & $\begin{array}{l}\text { Amount of energy transmitted } \\
\text { Amount of energy consumed }\end{array}$ & Absolute $(\mathrm{kW})$ \\
\hline
\end{tabular}

The depreciation amount according to this method is determined by the formula 3 :

$$
A=V \times C_{A} \times k,
$$

where $V$ - volume of production (work performed, services);

$C_{A}-$ absolute production rate of depreciation per unit volume;

$k$ - correction coefficient which consider the relative index (\%).

That is, the choice of the depreciation method should be based on the dependence of the method of their use on the degree of intensity of operation, taking into account the useful life.

Conclusions. To stimulate an increase in the optimality of the structure of fixed assets, it is necessary to implement the following priority measures at the legislative level:

1. To anticipate the possibility of forming a special reserve for updating fixed assets of food enterprises.

2. To anticipate the possibility of deferred depreciation, when in the case of losses the company may not accrue depreciation of fixed assets, and transfer it to a more favorable period without limitation in terms. The application of the method will help to reduce a number of unprofitable enterprises in the industry and as some of them come out of the crisis - the growth of capital investments to upgrade fixed assets.
3. If an irreversible asset is idle for any reason, depreciation should be accrued during the downtime, even if it does not create income for the enterprise. According to the authors, in this case, it is necessary to divide the depreciation charge into two parts:

- during the operation of the equipment the account of production or overhead costs are debited;

- during downtime its charged to the expenses of the reporting period.

4. To stimulate precisely expanded reproduction, rather then simple replacement due to depreciation, introduce an additional benefit for the growth of capital investments.

\section{References}

1. Polozhennya (standart) buhgalters'kogo obliku 7 «Osnovni zasobi» [Regulations (Standard) Accounting 7 "Fixed Assets"] (zatv. MFU 27.04.2000. № 92).

2. Lazarenko D.O. (2012). Mekhanizmi ta tekhnologii organizacii i upravlinnya pidpriemstvami harchovoi galuzi: naukovo-praktichniy aspekt: monografiya [Mechanisms and technologies of organization and management of food industry enterprises: scientific and practical aspect: monograph]. Herson, Grin' D.S. 454 p.

3. Lazarenko D.A., Sirenko S.V. (2002). Sravnitel'nyj analiz amortizacionnoj politiki [Comparative analysis of depreciation policy]. Ekonomika: problemi teorii ta 
praktiki: Nauk.-met. zb. Dnipropetrovs'k, MO-DNU. Vip. 135, pp. 157-165.

4. Lazarenko D.A. (2009). Vikoristannya pervinnoi informacii dlya potochnogo kontrolyu za stanom neoborotnih aktiviv. Zb. nauk. prac' «Aktual'ni problemi teorii i praktiki buhgalters'kogo obliku, analizu ta auditu v Ukraïni: suchasnij stan, tendencii ta perspektivi rozvitku», Vip.17, T.2 Collection of scientific labours, [Use primary information for current control of the state of fixed assets. Coll. of scientif. works "Actual problems of Theory and Practice of Accounting, Analysis and Audit in Ukraine: Modern status, trends and prospects]. Kam'yanec'Podil's'kij, Podil's'kij derzhavnij agrarno-tekhnichnij universitet, 2009, pp. 465-469.

5. Khendriksen E.S. Van Breda M.F. (1997). Teoriya bukhgalterskogo ucheta [The theory of accounting]. Moskva, Finansy` i statistika. 570 p.

6. Podatkovij kodeks Ukrayini [Tax Code of Ukraine] vi’d 02.12.2010 r. № 2755-VI.

7. Dźwigol, H.; \& Wolniak, R. (2018). Controlling w procesie zarządzania chemicznym przedsiębiorstwem produkcyjnym [Controlling in the management process of a chemical industry production company]. Przemysl Chemiczny, 97(7), 1114-1116. https://doi.org/10.15199/ 62.2018.7.15.

8. Dźwigoł, H., \& Dźwigoł-Barosz, M. (2018). Scientific research methodology in management sciences. Financial and Credit Activity. Problems of Theory and Practice, 2(25), 424-437. https://doi.org/10.18371/fcaptp. v2i25.136508.

9. Dzwigoł, H., Dzwigoł-Barosz, M., Zhyvko, Z., Miskiewicz, R., \& Pushak, H. (2019). Evaluation of the energy security as a component of national security of the country. Journal of Security and Sustainability Issues, 8(3), 307-317. http://doi.org/10.9770/jssi.2019.8.3(2).

10. Dzwigol, H., Aleinikova, O., Umanska, Y., Shmygol, N., \& Pushak, Y. (2019). An Entrepreneurship Model for Assessing the Investment Attractiveness of Regions. Journal of Entrepreneurship Education, 22(SI1), 1-7.

11. Boiko, V., Kwilinski, A., Misiuk, M., \& Boiko, L. (2019). Competitive advantages of wholesale markets of agricultural products as a type of entrepreneurial activity: the experience of Ukraine and Poland. Economic AnnalsXXI, 175(1-2), 68-72. https://doi.org/10.21003/ea.V175-12.

12. Savchenko, T., Basiurkina, N., Rodina, O., \& Kwilinski, A. (2019). Improvement of the assessment methods of product competitiveness of the specialized poultry enterprises. Management Theory and Studies for Rural Business and Infrastructure Development, 41(1), 4361. https://doi.org/10.15544/mts.2019.05.

13. Kwilinski, A., Volynets, R., Berdnik, I., Holovko, M., \& Berzin, P. (2019). E-Commerce: Concept and Legal Regulation in Modern Economic Conditions. Journal of Legal, Ethical and Regulatory Issues, 22(SI2), 1544-004422-SI-2-357: 1-6.

14. Kwilinski, A. (2018). Mechanism of modernization of industrial sphere of industrial enterprise in accordance with requirements of the information economy. Marketing and Management of Innovations, 4, 116-128. http://doi.org/10.21272/mmi.2018.4-11.
15. Kwilinski, A. (2019). Implementation of Blockchain Technology in Accounting Sphere. Academy of Accounting and Financial Studies Journal, 23(SI2), 15282635-23-SI-2-412: 1-6.

Лазаренко Д. О., Сіренко С. В., Джвігол Х., Джвігол-Барош М. Основні облікові аспекти амортизаційної політики та їі роль в процесі відновлення основних засобів харчових підприсмств

У статті розглянуто проблемні аспекти, що стосуються суті, обліку, економічного обгрунтування процесу амортизації та амортизаційної політики підприємств харчової галузі. Показано можливе рішення проблеми поліпшення фінансового забезпечення підприємства шляхом використання механізму відстрочених податків. Розкрито та проаналізовано основні критерії визначення інтенсивності експлуатації необоротних активів.

Ключові слова: економічний район, транспортнологістичний кластер, інституційні умови, чинники, механізм фінансового забезпечення, логістична діяльність, синергетичний ефект.

Lazarenko D., Sirenko S., Dzwigol H., DzwigolBarosz M. Basic Accounting Aspects of Amortization Politik and It's Role in the Process of Proceeding in the Fixed Assets (Property, Plant and Equipment) of Food Enterprises

The article discusses the problematic aspects relating to the nature, accounting, economic justification of the depreciation process and depreciation policy of food industry enterprises. A possible solution to the problem of improving the financial security of the enterprise by using the mechanism of deferred taxes is shown. The main criteria for determining the intensity of operation of non-current assets are disclosed and analyzed.

Keywords: economic region, transport and logistics cluster, institutional conditions, factors, financial support mechanism, logistics, synergistic effect.

Лазаренко Д. А., Сиренко С. В., Джвигол Х., Джвигол-Барош М. Основные учетные аспекты амортизационной политики и ее роль в процессе обновления основных фондов пищевых предприятий

В статье рассмотрены проблемные аспекты, касающиеся сущности, учета, экономического обоснования процесса амортизации и амортизационной политики предприятий пищевой отрасли. Показано возможное решение проблемы улучшения финансового обеспечения предприятия путем использования механизма отсроченных налогов. Раскрыты и проанализированы основные критерии определения интенсивности эксплуатации необотротных активов.

Ключевые слова: экономический район, транспортно-логистический кластер, институциональные условия, факторы, механизм финансового обеспечения, логистическая деятельность, синергетический эффект.

Received by the editors: 25.11 .2019 and final form 19.12.2019 